\title{
Congenital Mesoblastic Nephroma: A Rare Pediatric Neoplasm
}

\section{Kongenital Mezoblastik Nefrom: Nadir Bir Pediatrik Tümör}

\author{
Varuna MALLYA, Rashmi ARORA, Kusum GUPTA, Uma SHARMA
}

Department of Histopathology, Safdurjang Hospital and Vardhaman Mahavir Medical College, NEW DELHI, INDIA

\begin{abstract}
Congenital mesoblastic nephroma is a stromal neoplasm of infancy. It has been referred to as mesenchymal, cystic or leiomyomatous hamartoma. These tumors are centered around the hilus of the kidney. Mesoblastic nephromas need to be distinguished from other pediatric renal neoplasms as these lesions are treated by complete surgical excision without chemotherapy unless gross residual tumor remains. Here, we describe the gross and microscopic features of mesoblastic nephroma in a twenty-day old infant.
\end{abstract}

Key Words: Congenital mesoblastic nephroma, Kidney neoplasms, Infancy

\section{INTRODUCTION}

Stromal tumors account for $15 \%$ of all pediatric renal tumors. Congenital mesoblastic nephroma $(\mathrm{CMN})$ is a stromal neoplasm of infancy and has characteristic features that help to differentiate it from metanephric stromal tumor (MST) (1). CMN is centered around the hilus of the kidney and nearly all involve the renal sinus. Histopathologically, CMNs are predominantly monomorphic neoplasms composed of spindled mesenchymal cells of fibroblastic or myofibroblastic lineage. These are divided into two major types: classic and cellular (2). Almost all CMNs are predominantly localized to the kidney and perinephric or hilar soft tissue at the time of detection. Recurrences and metastasis occur in approximately 5 to $10 \%$ of all tumors. It is a very rare tumor and very few cases have been reported in the literature. Here we present a case in a 20-day-old infant.

\section{CASE REPORT}

A twenty-day-old female child presented with abdominal swelling. Ultrasonography revealed a solid mass in the right kidney. A provisional diagnosis of Wilms tumor was made and right nephrectomy was done. Histopathological

(Turk Patoloji Derg 2013, 29:58-60)

Received : 14.09 .2010 Accepted : 31.05 .2011

\section{Öz}

Konjenital mezoblastik nefrom, bebeklik döneminin stromal neoplazisidir. Mezenkimal, kistik veya leyomyomatöz hamartom olarak kabul edilmektedir. Bu tümörler böbrekte hilus civarında yerleşim gösterir. Mezoblastik nefromlar makroskopik rezidü olmadığ 1 takdirde kemoterapiye gerek kalmadan cerrahi eksizyon ile tedavi edildikleri için diğer pediatrik renal tümörlerden ayırt edilmelidir. Burada, 20 günlük bir bebekte saptanan mezoblastik nefromun makroskopik ve mikroskopik özellikleri tanımlanmaktadır.

Anahtar Sözcükler: Konjenital mezoblastik nefrom, Böbrek neoplazileri, bebeklik dönemi sections from the nephrectomy specimen showed features of mesoblastic nephroma with immunohistochemistry confirming the diagnosis.

The kidney measured $9 \times 7 \times 5 \mathrm{~cm}$. On cut section, the cortex and medulla could not be seen, and the kidney was replaced by a grey-white homogenous lesion having a whorled myomatous appearance. A thin segment of compressed normal kidney was seen. A small cyst measuring $1 \mathrm{~cm}$ in diameter was also noted (Figure 1).

Microscopy revealed a monomorphous lesion composed of interlacing fascicles of spindled cells. These cells were plump with moderate amount of cytoplasm and elongated vesicular nuclei. Dilated thin walled vascular spaces were also noted. The tumor margins were irregular, with radiating bands extending into the normal renal parenchyma (Figure 2). Entrapped renal glomeruli and tubules were also seen in the tumor (Figure 3). The medial margins of the kidney were free of tumor. Multiple sections did not show any blastemous component. Immunohistochemistry (IHC) for vimentin, actin and desmin were positive. Based on the microscopic appearance and IHC, a diagnosis of CMN was made.
Correspondence: Varuna MALLYA

Department of Histopathology, Safdurjang Hospital and Vardhaman Mahavir Medical College, NEW DELHI, INDIA

E-mail: varunasipayya@gmail.com Phone: 556919106192 


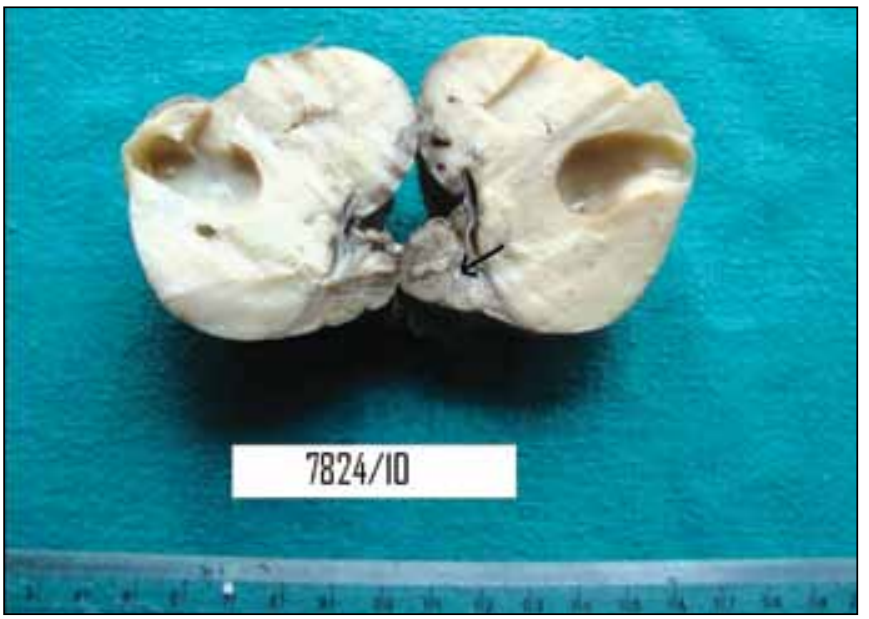

Figure 1: Gross photo showing cut section of kidney having a whorled myomatous appearance. Normal parenchyma is noted at the lower pole (arrow).

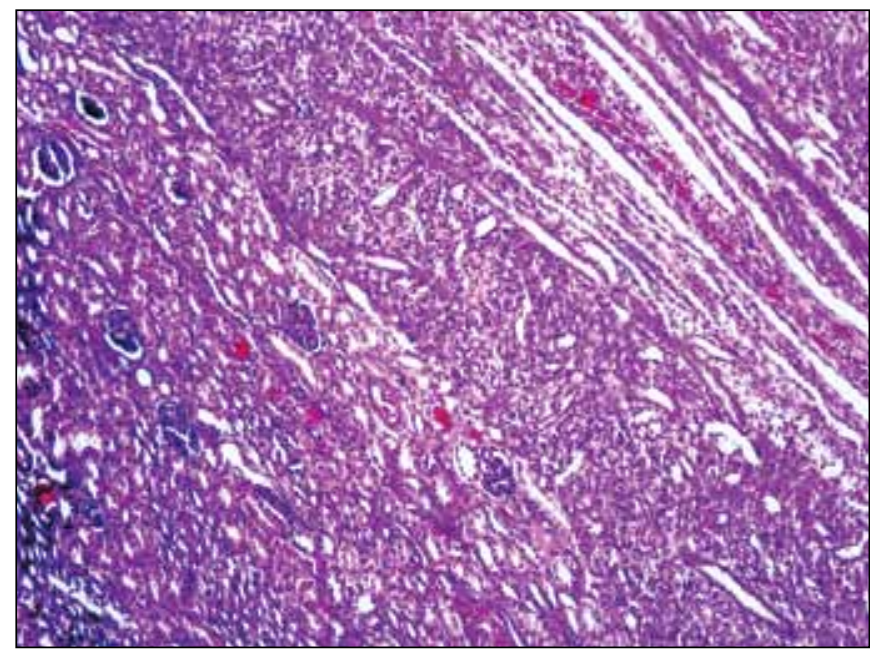

Figure 2: Photomicrograph showing lesion composed of interlacing fascicles of spindled cells with radiating bands extending into the normal renal parenchyma (H\&E, x400).

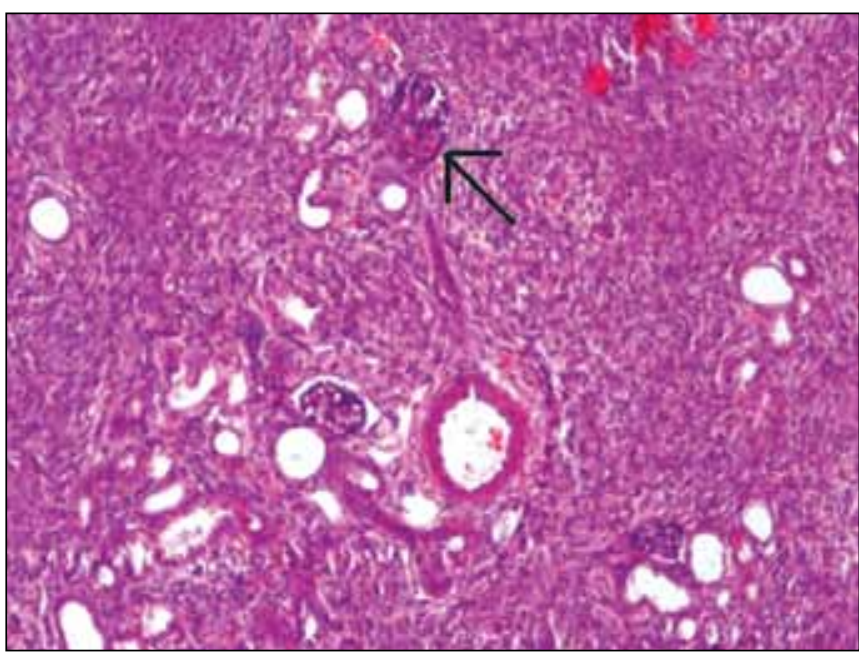

Figure 3: Photomicrograph showing entrapped renal glomeruli (arrow) and tubules within the tumor (H\&E, x400).

\section{DISCUSSION}

$\mathrm{CMN}$ is an under-reported pediatric neoplasm of the kidney with a good prognosis. This tumor needs to be distinguished from Wilms tumor, metanephric stromal tumor (MST) and clear cell sarcoma of the kidney (CSSK) $(1,2)$.

$\mathrm{CMN}$ is diagnosed in the first few months of life. It may even present in utero, causing non-immune hydrops and polyhydramnios (2).

Mesoblastic nephromas grossly appear as solitary, unilateral masses with firm, bulging cut surfaces often indistinguishable from nephroblastomas that have been treated with chemotherapy. Cysts, haemorrhage and necrosis are common. However, some lesions are quite firm. Most CMNs are centered around the hilus of the kidney and mostly involve the renal sinus, and careful surgical and pathological examination of the medial aspect of the nephrectomy and its medial margin is therefore of paramount importance.

Histologically, they are composed of spindled mesenchymal cells of fibroblastic or myofibroblastic lineage and are thought to arise from secondary mesenchyme. Two histological subtypes have been described: classic and cellular type (1). The classic type resembles infantile fibromatosis with interlacing fascicles of spindle cells, resembling fibroblasts, myofibroblasts, interspersed with scant collagen fibres. Tumor margins are highly irregular with radiating tongues of cells extending into the parenchyma and perirenal soft tissues (2). Abnormal metaplastic changes in the tubules or glomeruli adjacent to or entrapped by the lesion are present. Only $24 \%$ of CMNs are of the classic type. The cellular type, which is more common, is characterized by increased cellular density and high proliferative rate, imparting a sarcomatous appearance to the tumor. Mitotic activity is more conspicuous than the classic type (1). Cellular and classic patterns coexist and they are described as mixed mesoblastic nephroma. Extramedullary hematopoiesis can be observed. Skeletal muscle differentiation is not a feature of CMN. Our case showed the classic pattern. CMNs are positive for vimentin, actin and desmin. The onion skin rings of muscle (collarettes) around tubules and blood vessels, juxtaglomerular hyperplasia, angiodysplasia and desmin negativity, which are characteristic features of MST, were absent in our case distinguishing it from MST (3). The characteristic branching vasculature and diversity of patterns which are specific to CSSK help to distinguish it from CMN. Our case could be distinguished from Wilms tumor that had been treated with chemotherapy by the 
absence of blastematous foci on histology. Wilms tumor is also seen after six months of age.

All CMNs behave clinically in a benign fashion and it is therefore important to differentiate them from aggressive mimics as nephrectomy is curative (4). There is a case reported to undergo spontaneous regression (5).

This communication highlights a case of $\mathrm{CMN}$, an underreported pediatric renal neoplasm with a good prognosis after total excision.

\section{REFERENCES}

1. Agrani P, Beckwith JB: Renal Neoplasma of Childhood. In Mills SE. (Ed.): Sternberg's Diagnostic Surgical Pathology. 4th ed., Philadelphia, Lippincott Williams and Wilkins, 2004:2016-2019

2. $\boldsymbol{W} \boldsymbol{u} E$ : Pathologic quiz case: A renal tumor in a newborn child. Arch Pathol Lab Med 2002,126:103-104

3. Rajalakshmi V, Chandran P, Selvambigai, Ganesh J: Metanephric stromal tumor: A novel pediatric renal neoplasm. Indian J Pathol Microbiol 2009, 52:389-391

4. Khashu M, Osiovich H, Sargent MA: Congenital mesoblastic nephroma presenting with neonatal hypertension. J Perinatol 2005, 25:433-435

5. Whittle S, Gosain A, Brown PY, Debelenko L, Raimondi S, Wilimas JA, Jenkins JJ, Davidoff AM: Regression of a congenital mesoblastic nephroma. Pediatric Blood Cancer 2010, 55:364-368 